\title{
CONFIRMED WINTER RESIDENCY OF COMMON GOLDENEYE AND COMMON MERGANSER IN THE NORTHWEST TERRITORIES.
}

\section{JACQUES SIROIS, 1203-717 Victoria Ave., Saskatoon, SK. S7N 2T5}

On 12 December 1990 one male Common Goldeneye was at Jackfish Lake in Yellowknife $\left(62^{\circ} 28^{\prime} \mathrm{N}, 114^{\circ}\right.$ 22'W; Fig. 1), Northwest Territories (NWT), where effluents from a diesel power plant maintain two patches (ca. $100 \mathrm{~m}^{2}$ ) of open water throughout the winter. The bird remained on this lake, which I visited every two to three days, until 23 February 1991.
Thus it spent more than two winter months at Yellowknife.

I went to the Tartan Rapids of the Yellowknife River, $15 \mathrm{~km}$ northeast of Jackfish Lake, on 3 March 1991 to look for the goldeneye. This ice-free area includes the rapids (ca. $30 \mathrm{x}$ $100 \mathrm{~m}$ ), and a large pool below the rapids that is often more than $300 \mathrm{~m}$

\begin{tabular}{|c|c|c|}
\hline Source & Species and Number & $\begin{array}{l}\text { Location (Figure 1), } \\
\text { Date and Comment }\end{array}$ \\
\hline R. Bromley (pers. comm.) & Common Merganser, 1 at least. & $\begin{array}{l}\text { Yellowknife River, below "Con } \\
\text { Hydro" }\left(62^{\circ} 42^{\prime} \mathrm{N} 114^{\circ} 20^{\prime} \mathrm{W}\right) \text {, where } \\
\text { open water occurs year-round, one } \\
\text { winter month in the } 1960 \text { s. }\end{array}$ \\
\hline W. Carpenter (pers. obs.) & Unident. diving ducks, a few. & $\begin{array}{l}\text { Cameron River }\left(62^{\circ} 50^{\prime} \mathrm{N}, 114^{\circ}\right. \\
\left.10^{\prime} \mathrm{W}\right) \text {, February } 1972 .\end{array}$ \\
\hline Scotter et al. (1985) & $\begin{array}{l}\text { American Dipper, } 2 . \\
\text { Mallard, } 2 .\end{array}$ & $\begin{array}{l}\text { Wild Mint Springs (ca. } 61^{\circ} 30^{\prime} \mathrm{N} \text {, } \\
126^{\circ} 30^{\prime} \mathrm{N} \text { ), Nahanni National Park } \\
\text { Reserve, } 25 \text { February } 1977 . \\
\text { Suspected to be year-round } \\
\text { residents. } \\
\text { Same location, date and comment. }\end{array}$ \\
\hline K. Poole (pers. obs.) & Common Merganser, 1. & $\begin{array}{l}\text { Yellowknife River, below Tartan } \\
\text { Rapids }\left(62^{\circ} 41^{\prime} \mathrm{N}, 114^{\circ} 15^{\prime} \mathrm{W}\right) \text {, ca. } 10 \\
\text { March } 1984 \text { or } 1985 .\end{array}$ \\
\hline J. Sirois (pers. obs.) & Mallard, 1. & $\begin{array}{l}\text { Yellowknife River, Tartan Rapids, } 26 \\
\text { January } 1987 .\end{array}$ \\
\hline Sirois (1991) & $\begin{array}{l}\text { Black Guillemot, } 1 . \\
\text { Red-necked Grebe, } 1 .\end{array}$ & $\begin{array}{l}\text { Cameron River }\left(62^{\circ} 27^{\prime} \mathrm{N}, 114^{\circ}\right. \\
\left.22^{\prime} \mathrm{W}\right), 26 \text { November } 1988 . \\
\\
\text { Offshore, Great Slave Lake }\left(61^{\circ}\right. \\
\left.55^{\prime} \mathrm{N}, 114^{\circ} 20^{\prime} \mathrm{W}\right) \text { where water had } \\
\text { not frozen yet, } 15 \text { December } 1988 . \\
\end{array}$ \\
\hline G. Stenhouse (pers. obs.) & Mallard, 20. & $\begin{array}{l}\text { Walker Creek Lake }\left(65^{\circ} 20^{\prime} \mathrm{N}, 128^{\circ}\right. \\
\left.30^{\prime} \mathrm{W}\right) \text {, January } 1988, \text { where springs } \\
\text { keep water open year-round. }\end{array}$ \\
\hline D. Dubé (pers. obs.) & Unident. ducks, 6. & $\begin{array}{l}\text { Camsel River }\left(65^{\circ} 35^{\prime} \mathrm{N}, 117^{\circ} 45^{\prime} \mathrm{N}\right) \text {, } \\
17 \text { January } 1989 .\end{array}$ \\
\hline J.Sirois (pers.obs.) & Lesser Scaup, 1. & $\begin{array}{l}\text { Jackfish Lake in Yellowknife, 12-16 } \\
\text { December } 1990 .\end{array}$ \\
\hline
\end{tabular}




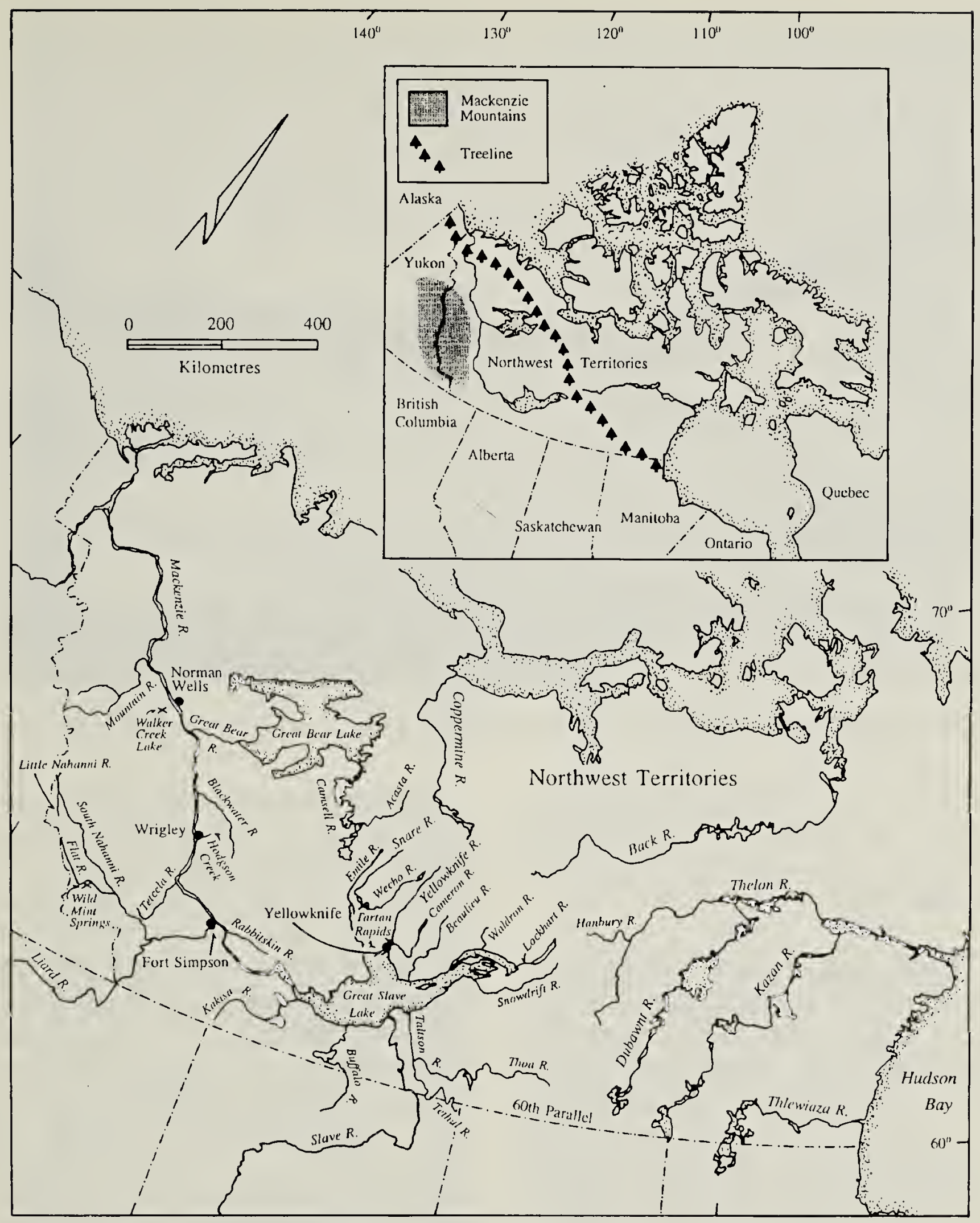

Figure 1. Southwestern Northwest Territories: rivers and other sites with ice-free water throughout the winter (Source: F.M. Conly, Environment Canada, Yellowknife).

long. One male Common Merganser was there.

I returned to the Tartan Rapids eight times through 18 April. During each visit, the merganser was either loafing, sleeping, diving, or preening its feathers. On a subsequent visit, on 20 April, three more Common Mergansers, presumably newly arrived spring migrants, were there.
Thus a Common Merganser spent at least seven late-winter weeks at the Tartan Rapids during March and April 1991.

To my knowledge, these are the first confirmed records of winter residency for these species in the NWT. However, these are not the first winter sightings of waterbirds in NWT freshwaters (Table 1). Other ducks, 


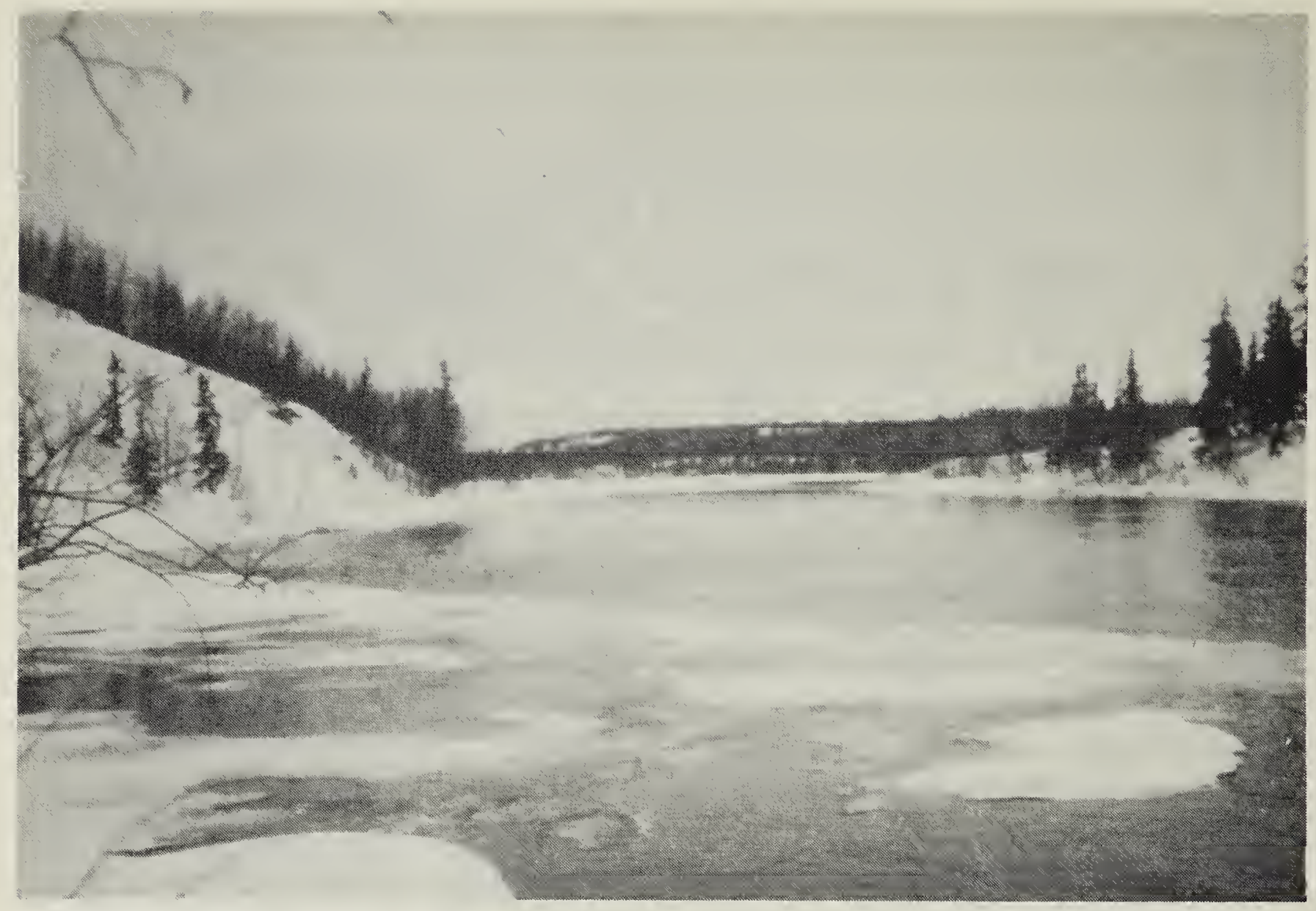

as well as some gulls and auks, are known or suspected to winter in polynyas and other ice-free marine waters. ${ }^{1,4,9}$

As far as I know, no duck has been reported during the winter in NWT lakes or rivers since April 1991 but it is possible that some have wintered there again as ice-free habitat is available at several sites. Open water occurs in more than 30 rivers or lakes during the winter (Fig. 1) and often at numerous sites along the same river.

I suspect that waterbirds winter regularly in NWT, particularly in the Mackenzie Mountains (Fig. 1), where fast-moving rivers and springs provide reliable ice-free water yearround. This is suggested by the numerous winter records of ducks in the Yukon (P. Sinclair, unpubl. data) where habitat is similar to that of the Mackenzie Mountains and Common Merganser and Common Goldeneye are confirmed winter residents. ${ }^{13}$
Confirmation of wintering by Common Goldeneye and Common Merganser in southwestern NWT is not surprising in light of the numerous winter sightings and confirmed and suspected winter residency records of these two species in Saskatchewan and Alberta. ${ }^{6,7,8,10,15}$ I suspect that waterbirds will winter more frequently in NWT freshwaters in the future. Climate-warming trends in western NWT have shown the greatest overall increase $\left(1.7^{\circ} \mathrm{C}\right)$ in Canada in the last century. ${ }^{5}$ This should lengthen the ice-free season, as documented elsewhere, and result in larger amounts of ice-free water where it already occurs. ${ }^{11}$

1990 was the warmest year on record worldwide, and southern Canada and most of the U.S. were among the areas where this was most pronounced. ${ }^{2}$ Whether this favoured the winter residency of these two ducks at.Yellowknife is unclear. Locally, the 1990-1991. winter was not unusually warm: November and 
December 1990 were colder than normal (mean daily $\mathrm{T}^{\circ} \mathrm{C}$ : -20.6 and 29.1, respectively); January, February and April 1991 were slightly warmer $(-26.9,-23.8$, and -4.8 , respectively); and temperatures were normal in March 1991 (Environment Canada, unpub. data).

Acknowledgements I thank $A$. Downey for drafting the map, G. Meunier for taking the picture of the Tartan Rapids, and the Canadian Wildlife Service for its logistical support.

1. ABRAHAM, K.F. and G.H. FINNEY. 1986. Eiders of the eastern Canadian Arctic. In: Reed, A., editor. Eider ducks in Canada. Report Series No. 47, Canadian Wildlife Service. Ottawa. Pp. 55-73.

2. ANONYMOUS. 1991. 1990 hottest year. Climate Institute. Washington. Climate Alert 4:1.

3. ANONYMOUS. 1993. Canadian climate normals - Yukon and Northwest Territories. Canadian Climate Program, Atmospheric Environment Service. Ottawa. 58 pp.

4. BROWN, R.G.B. and D.N. NETTLESHIP. 1981. The biological significance of polynyas to arctic colonial seabirds. In: Stirling, I. and $\mathrm{H}$. Cleator, editors. 1981. Polynyas in the Canadian Arctic. Occasional Paper No. 45, Canadian Wildlife Service. Ottawa. Pp. 5965.

5. ULLETT, D.W. and W.R. SKINNER. 1992. L'état du climat au Canada: les variations de la température au Canada, 1895-1991. Rapport sur l'état de l'environnement $n^{\circ}$ 92-2. Service de l'environnement atmosphérique. Ottawa. $36 \mathrm{pp}$.
6. HARRIS, W.C. 1991. 49th Annual Saskatchewan Christmas Bird Count 1990. Blue Jay 49:7-26.

7. KOES, R.F. and P. TAYLOR. 1991. Prairie Provinces region. Winter 19901991. Am. Birds 45:287.

8. NIENAM, D.J. and R.J. ISBISTER. 1976. Waterfowl wintering in Saskatchewan, 1975/76. Unpublished Report, Canadian Wildlife Service. Saskatoon. 18 pp.

9. RENAUD,W.E. and M.S.W. BRADSTREET. 1980. Late winter distribution of Black Guillemots in northern Baffin Bay and the Can. High Arctic. Can. Field-Nat. 94:421-425.

10. SALT, W.R. and J.R. SALT. 1976 The Birds of Alberta. Hurtig Publishers. Edmonton. 498 pp.

11. SCHINDLER, D.W., K.G. BEATY, E.J. FEE, D.R. CRUIKSHANK, E.R. DEBRUYN, D.L. FINDLAY, G.A.A LINSEY, J.A. SHEARER, M.P. STAINTON, and M.A. TURNER. 1990. Effects of climate warming on lakes of the central boreal forest. Science 250:967-970.

12. SCOTTER, G.W., L.N. CARBYN, W.P. NEILY and J.D. HENRY. 1985. Birds of Nahanni National Park, Northwest Territories. Special Publication No. 15, Saskatchewan Natural History Society. Regina. 73 pp.

13. SIDDLE, C. 1994. Regional reports. British Columbia/Yukon Region. Field Notes 48:241.

14. SIROIS, J. 1991. First record of the Black Guillemot near Yellowknife, Northwest Territories. Blue Jay 49:3334.

15. SLATER, A.C. 1991. Alberta Christmas Bird Counts 1990. Alberta Nat. 21:59-71.

Some of the harshest deserts of the world are home to unique ensembles of insects, lizards and flowering plants. In the Namib of southwestern Africa, beetles use leg tips expanded into oarlike sand-shoes to swim down through the shifting dunes in search of dried vegetable matter. Others, the swiftest runners of the insect world, race over the baking hot surface on bizarre stilt legs. E.O. Wilson, The diversity of life. W.W. Norton and Company, New York. 